\title{
Biology and Ultra-structure of Trypanosoma cruzi: a 90-years Old Challenge for Scientists
}

\author{
Tania C de Araújo-Jorge \\ Laboratório de Biologia Celular, Departamento de Ultra-estrutura e Biologia Celular, Instituto Oswaldo Cruz, \\ Av. Brasil 4365, 21045-900 Rio de Janeiro, RJ, Brasil
}

Key words: Trypanosoma cruzi - biology - ultra-structure

When Dr Carlos Chagas first observed under the microscope the flagellate that he named Schizotrypanum cruzi (today known as Trypanosoma cruzi), in honor of his master and friend Oswaldo Cruz, he began to study the biology of this interesting microorganism (Chagas 1909). This unique fact in medicine, a single person's discovery and report of the clinical picture of a new disease, with a new etiological agent, its life cycle, its vectors and wild reservoirs, were later explained by himself (Chagas 1922): a process that he was able to understand after the intense and basic studies on the biology of this parasite, carried out at the Oswaldo Cruz Institute. In Chagas' own words “...quando no sangue periférico de uma criança febril, observamos o flagelado patogênico, de sua biologia já possuíamos noção completa, adquirida em demorados estudos anteriores" "...when we found the pathogenic flagellate in the blood of a children, we had already a complete notion of its biology, acquired under previous and detailed studies" (Chagas 1922).

Since then, the intriguing biology of this special parasite has been studied. Its morphology, depicted under the optical microscopy of Carlos Chagas and Garpar Vianna, was first investigated under an electron microscope by Dr Hertha Meyer (Meyer \& Porter 1954). Dr Carlos Chagas Filho, Chagas' son who founded in Rio de Janeiro the famous Institute of Biophysics that later took his name, achieved to establish Dr Hertha Meyer in this Institute during the II World War. She started a whole school of cell biology of $T$. cruzi (as well as other tropical disease parasites), introducing in vitro cell culture of muscle and nerve cells, and the ultrastructure study of all the parasite developmental stages (reviewed in De Souza 1984). Since Dr Chagas' time, some basic questions still chal-

Fax: +55-21-260.4434. E-mail: taniaaj@ioc.fiocruz.br Received 9 June 1999

Accepted 9 August 1999 lenge the intelligence and curiosity of scientists all over the world. Why and how does the parasite evolve among three different morphological and functional states of differentiation over its life cycle (ama-, epi- and trypomastigotes)? Does the T. cruzi slender and stout forms found in blood stream of different host represent sexual dimorphism or anything else? How does $T$. cruzi enter so many different cells? How does at least part of the parasite population that infects a person or animal escape the vigorous specific immune response elicited in the host by the infection, leading to the finding of viable forms during the decades-lasting chronic development of the disease?

During the 90 years that followed since Chagas' classic report of a new disease, much information was obtained on the biology and ultrastructure of its causative agent. Recent reviews from Dr Wanderley De Souza $(1984,1995)$ summarize the knowledge in this area. A large knowledge was obtained on the understanding of its clonal composition (Heckert et al. 1994, Tibayrenc 1995), as well as in its population distribution and associated biological and molecular markers (Zingales et al. 1998). Another important field on parasite biology investigation concerns its metabolic pathways (reviewed in Cazzulo 1992), that engages the design of new drugs based on differences encountered. Key organelles from which the parasite gets energy such as acid calcisomes (DoCampo et al. 1995) and reservosomes (Figueiredo et al. 1994) are under intense study. The same happens with some pivotal enzymes for the parasite that are involved in energy production (such as glycosomal enzymes, purine and sterol byosynthetic pathways), detoxification (such as trypanothione reductase, ornithine decarboxylase and S-adenosylmethionine decarboxylase), or virulence (such as cysteine proteases) mechanisms. Second generation anti-trypanocidal drugs will certainly emerge from this field of research (Krauth-Siegel \& Schoneck 1995, Cazzulo et al. 1997, Croft 1999, Urbina 1999) to substitute for the same two old and toxic drugs that are currently available for clinical use since the sixties (benznidazole and nifurtimox). 
Concerning the mechanisms of invasion, despite a search in the MedLine database find 155 indexed references on this matter among the 5206 references found with the key-word T. cruzi in the last 45 years (about $3 \%$ ), much efforts are yet to be done before a clear and consensual comprehension emerges. Since the classical studies of Dias (1934), Kofoid et al. (1935) and Hertha Meyer (Meyer \& Xavier-de-Oliveira 1948), we know that, depending on the parasite strain, it takes less than 20 min to $T$. cruzi to enter a cell. It proliferates through binary division along 2 to 9 cycles and fully fills the host cells' cytoplasm in 4-5 days, leading to cell rupture and release of new trypomastigotes. After invasion, it takes 1-2 hr for the parasite to disrupt the vacuolar membrane (Burleigh \& Andrews 1995), 2-3 hr to transform into amastigotes and enter the G1/G2 phases of the cell cycle, 24-44 hr to synthesize DNA. Amastigotes' generation time takes 8-15 hr, depending on the parasite strain, but cytokynesis is fast, taking 20-30 min (Hyde \& Dvorak 1973). In all cell types studied up to now the same negative binomial distribution of infected-cells was found (Hyde \& Dvorak 1973, Pécora et al. 1980), indicating that during the first $24 \mathrm{hr}$ of parasite-cell contact, cells that are already infected are more susceptible to a second invasion, probably because cell surface charge changes after infection (Soeiro et al. 1994). T. cruzi can enter experimentally enucleated cells but these cells do not support the complete development of the parasite (Osuna et al. 1983). In primary cultures of macrophages and muscle cells (not in some established cell lineages) the parasite can only invade living cells (Barbosa $\&$ Meirelles 1995), indicating an active role of the host cell itself. A complex panel of multiple ligands and receptors involved in host cell recognition, adhesion and penetration emerge from many studies and were reviewed in recent work (Araújo-Jorge et al. 1992, Vermelho \& Meirelles 1994, Burleigh \& Andrews 1995, 1998, Coutinho et al. 1998). This multiplicity of molecules involved in $T$. cruzi invasion, delayed the theoretic development of parasite entry blockade through rationally designed drugs or vaccines. However, successful approaches for DNA based-vaccines were recently reported, (a) for a transialidase gene (Costa et al. 1999), and (b) for a trypomastigote surface antigen that is a target of anti-T. cruzi antibody and major histocompatibility complex class I-restricted CD8+ cytotoxic T-lymphocyte responses (Wizel et al. 1998).

Different strategies for invasion were found to be used when the parasite faces different host cell types: active penetration, active induction of receptor-mediated phagocytosis, and opsonin-medi- ated phagocytosis. Especially important contributions came from in vitro studies using primary cardiomyocyte cell cultures, the most relevant host cell for the parasite in vivo. The main process of invasion occurs by active induction of phagocytosis, which is $70 \%$ sensitive to cytochalasin blockage (Barbosa \& Meirelles 1995). Parasitophorous vacuole formation and phago-lysosome fusion occurred (Meirelles et al. 1986), but in muscle cells vacuole membrane formation is not strictly dependent on lysosome recruitment, as described for cell lineages (Tardieux et al. 1992). Activation of cardiomyocyte trypanocidal mechanisms under cytokine effect was very recently found, through NO synthase induction and NO secretion (Chandrasekar et al. 1998, Machado 1999).

Concerning the mechanisms that the parasite evolved to ensure safe survival for at least part of its population, under the vigorous pressure of a specific immune response elicited in the host by the infection, there is also much effort to be addressed. How the parasite renders almost invisible an infected cell in an immune-competent chronic infected person or animal? Parasite molecules that depress directly or indirectly the immune response or interfere with it (Frank 1992), modulation of the infected host cell adhesion molecules, such as MHC (Meckert et al. 1991, Stryker \& Nickell 1995, Zhang \& Tarleton 1996, La Flamme et al. 1997), integrin (Savino \& Barbosa 1996) and lectin receptors (Kahn et al. 1995, Soeiro et al. 1999), alterations of the extracellular matrix (Andrade et al. 1989, Morris et al. 1990), or even parasite DNA incorporation in the cell genome (Teixeira et al. 1994) were already reported, but have not completed the puzzle. Recent work also re-analyzed important changes induced inside the infected cell, such as cell uncoupling by affecting gap junctions (Carvalho et al. 1994), cytoskeletal alterations (Pereira et al. 1993) and organelle rearrangement.

The round table that Dr Brener and I have the pleasure to introduce in this meeting will discuss some of the fascinating points that are still unknown in these fields. As throughout animal kingdom, life for a trypanosome is essentially a question of eat, survive and reproduce under different nutritional conditions and sources. T. cruzi has evolved an interesting biology, adapted to different environments in vertebrate and invertebrate hosts, and to store enough energy source to assure its reproduction and survival under so different situations. I am sure that answers and new questions will clearly appear during the presentations of the round-table components.

\section{REFERENCES}

Andrade SG, Grimaud JA, Stocker-Guerret S 1989. Sequential changes of the connective matrix compo- 
nents of the myocardium (fibronectin and laminin) and evolution of cardiac fibrosis in mice infected with Trypanosoma cruzi. Am J Trop Med Hyg 40: 252-260.

Araújo-Jorge TC, Barbosa HS, Meirelles MN 1992. Trypanosoma cruzi recognition by macrophages and muscle cells: perspectives after a 15-year study. Mem Inst Oswaldo Cruz 87 (Suppl.) 5: 43-56.

Barbosa HS, Meirelles MN 1995. Evidence of participation of cytoskeleton of heart muscle cells during the invasion of Trypanosoma cruzi. Cell Struct Funct 20: 275-284.

Burleigh BA, Andrews NW 1995. The mechanism of Trypanosoma cruzi invasion of mammalian cells. Annu Rev Microbiol 49: 175-200.

Burleigh BA, Andrews NW 1998. Signaling and host cell invasion by Trypanosoma cruzi. Curr Opin Microbiol 1: 461-465.

Carvalho AC, Masuda MO, Tanowitz HB, Wittner M, Goldenberg RC, Spray DC 1994. Conduction defects and arrhythmias in Chagas' disease: possible role of gap junctions and humoral mechanisms. $J$ Cardiovasc Electrophysiol 5: 686-698.

Cazzulo JJ 1992. Energy metabolism in Trypanosoma cruzi. Subcell Biochem 18: 2 35-257.

Cazzulo JJ, Stoka V, Turk V 1997. Cruzipain, the major cysteine proteinase from the protozoan parasite Trypanosoma cruzi. Biol Chem 378: 1-10.

Chagas C 1909. Nova tripanosomiaze humana. Estudos sobre a morfologia e o ciclo evolutivo do Schizotrypanum cruzi n. g., n. sp., agente etiologico de nova entidade morbida do homem. Mem Inst Oswaldo Cruz 1: 159-218.

Chagas C 1922. Descoberta do Trypanosoma. cruzi e verificação da tripanozomiase americana. Mem Inst Oswaldo Cruz 15: 67-76.

Chandrasekar B, Melby PC, Troyer DA, Colston JT, Freeman GL 1998. Temporal expression of pro-inflammatory cytokines and inducible nitric oxide synthase in experimental acute chagasic cardiomyopathy. Am J Pathol 152: 925-934.

Costa F, Pereira-Chioccola VL, Ribeirao M, Schenkman S, Rodrigues MM 1999. Trans-sialidase delivered as a naked DNA vaccine elicits an immunological response similar to a Trypanosoma cruzi infection. Braz J Med Biol Res 32: 235-239.

Coutinho CMLM, Cavalcanti GH, Bonaldo MC, Mortensen RF, Araujo-Jorge TC 1998 Trypanosoma cruzi: detection of a surface antigen cross-reactive to human C-reactive protein. Exp Parasitol 90: 143153.

Croft SL 1999. Pharmacological approaches to antitrypanosomal chemotherapy. Mem Inst Oswaldo Cruz 94: 215-220.

De Souza W 1984. Cell Biology of Trypanosoma cruzi. Int Rev Cytol 86: 197-283.

De Souza W 1995. Structural organization of the cell surface of pathogenic protozoa. Micron 26: 405-430.

Dias E 1934. Estudos sobre o Schizotrypanum cruzi. Mem Inst Oswaldo Cruz, 27: 1-110.

DoCampo R, Scott DA, Vercesi AE, Moreno SNJ 1995. Intracellular $\mathrm{Ca} 2+$ storage in acidocalcisomes of
Trypanosoma cruzi. Biochem J 310: 1005-1012.

Figueiredo RC, Steindel M, Soares MJ 1994. The reservosomes of epimastigote forms of Trypanosoma cruzi: occurrence during in vitro cultivation. Parasitol Res 80: 517-522.

Frank MM 1992. The mechanism by which microorganisms avoid complement attack. Curr Opin Immunol 4: 14-19.

Hecker H, Betschart B, Bender K, Burri M, Schlimme W 1994. The chromatin of trypanosomes. Int J Parasitol 24: 809-819.

Hyde TP, Dvorak JA 1973. Trypanosoma cruzi: interaction with vertebrate cells in vitro. 2. Quantitative analysis of the penetration phase. Exp Parasitol 34: 284-294.

Kahn S, Wleklinski M, Aruffo A, Farr A, Coder D, Kahn M 1995. Trypanosoma cruzi amastigote adhesion to macrophages is facilitated by the mannose receptor. $J$ Exp Med 182: 1243-1258.

Kofoid CA, Wood FD, McNeil E 1935. The cycle of Trypanosoma cruzi in tissue culture of embryonic heart muscle cell. Unit Calif Publi Zool 41: 23-24.

Krauth-Siegel RL, Schoneck R 1995. Flavoprotein structure and mechanism. 5. Trypanothione reductase and lipoamide dehydrogenase as targets for a structurebased drug design. FASEB J 9: 1138-1146.

La Flamme AC, Kahn SJ, Rudensky AY, Van Voorhis WC 1997. Trypanosoma cruzi-infected macrophages are defective in major histocompatibility complex class II antigen presentation Eur J Immunol 27: 30853094.

Machado FS 1999. Atividade Tripanocida e PróInflamatória de Miócitos de Camundongos Infectados com Trypanosoma cruzi, MSc Thesis, Fac. Med. Ribeirão Preto, USP.

Meckert PC, Hontebeyrie-Joskowicz M, Chambo J, Levin M, Laguens RP 1991. Trypanosoma cruzi: aberrant expression of class II major histocompatibility complex molecules in skeletal and heart muscle cells of chronically infected mice. Exp Parasitol 72: 8-14.

Meirelles MN, Araujo-Jorge TC, Miranda CF, de Souza W, Barbosa HS 1986. Interaction of Trypanosoma cruzi with heart muscle cells: ultrastructural and cytochemical analysis of endocytic vacuole formation and effect upon myogenesis in vitro. Eur J Cell Biol 41: 198-206.

Meyer H, Xavier de Oliveira M 1948. Cultivation of Trypanosoma cruzi in tissue culture: a four year study. Parasitology 39: 91-94.

Meyer H, Porter KR 1954. A study of Trypanosoma cruzi with the electron microscope. Parasitology 44: 1623.

Morris SA, Wittner M, Weiss L, Hatcher VB, Tanowitz HB, Bilezikian JP, Gordon PB 1990. Extracellular matrix derived from Trypanosoma cruzi infected endothelial cells directs phenotypic expression. $J$ Cell Physiol 145: 340-346.

Osuna A, Jimenez-Ortiz A, Mascaro C, Alonso C 1983. Trypanosoma cruzi: arrested division of amastigote forms in enucleated HeLa cells. J Parasitol 69: 629631. 
Pecora IL, dos Reis GA, Barcinski MA, Dorigo DD 1980. Frequency distribution of Trypanosoma cruzi in macrophages from resistant and susceptible strains of mice. Experientia 36: 942-944.

Pereira MC, Costa M, Chagas Filho C, de Meirelles MN 1993. Myofibrillar breakdown and cytoskeletal alterations in heart muscle cells during invasion by Trypanosoma cruzi: immunological and ultrastructural study. J Submicrosc Cytol Pathol 25: 559-569.

Savino W, Silva-Barbosa SD 1996. Laminin/VLA-6 interactions and T cell function. Braz J Med Biol Res 29: $1209-1220$

Soeiro MN, Silva-Filho FC, Meirelles MN 1994. The nature of anionic sites and the endocytic pathway in heart muscle cells. J Submicrosc Cytol Pathol 26: 121-130.

Soeiro MNC, Paiva MM, Barbosa HS, Meirelles MNSL, Araújo-Jorge TC 1999. A cardiomyocyte mannose receptor system is involved in Trypanosoma cruzi invasion and is down modulated after infection. Cell Struct \& Func, in press.

Stryker GA, Nickell SP 1995. Trypanosoma cruzi: exposure of murine cells to live parasites in vitro leads to enhanced surface class I MHC expression which is type I interferon-dependent. Exp Parasitol 81: 564573.

Tardieux I, Webster P, Ravesloot J, Boron W, Lunn JA, Heuser JE, Andrews NW 1992. Lysosome recruitment and fusion are early events required for trypanosome invasion of mammalian cells. Cell 71: 1117 -
1130.

Teixeira AR, Arganaraz ER, Freitas LH Jr, Lacava ZG, Santana JM, Luna H 1994. Possible integration of Trypanosoma cruzi $\mathrm{kDNA}$ minicircles into the host cell genome by infection. Mutat Res 305: 197-209.

Tibayrenc M 1995. Population genetics of parasitic protozoa and other microorganisms Adv Parasitol 36: 47-115.

Urbina JA 1999. Chemotherapy of Chagas' disease: the how and the why. J Mol Med 77: 332-338.

Vermelho A, Meirelles MNL 1994. Sialoglycoconjugates in Trypanosoma cruzi-host cell interaction: possible biological models - a review. Mem Inst Oswaldo Cruz 89: 69-79.

Wizel B, Garg N, Tarleton RL 1998. Vaccination with trypomastigote surface antigen 1-encoding plasmid DNA confers protection against lethal Trypanosoma cruzi infection. Infect Immun 66: 5073-5081.

Zhang L, Tarleton RL 1996. Persistent production of inflammatory and anti-inflammatory cytokines and associated MHC and adhesion molecule expression at the site of infection and disease in experimental Trypanosoma cruzi infections. Exp Parasitol 84: 203-213.

Zingales B, Souto RP, Mangia RH, Lisboa CV, Campbell DA, Coura JR, Jansen AM, Fernandes O 1998. Molecular epidemiology of american trypanosomiasis in Brazil based on dimorphisms of rRNA and mini-exon gene sequences. Int J Parasitol 28: 105112. 